\title{
THE PHYSIOTHERAPEUTIC TREATMENT OF CEREBRAL PALSIED CHILDREN
}

\author{
By A. OBHOLZER, M.D., Ph.D.
}

\begin{abstract}
A Lecture delivered at the Meeting of the Kimberley Branch of the South African Society of Physiotherapists
at the Helen Bishop Home in Kimberley on 25th August, 1951.
\end{abstract}

\begin{abstract}
$\mathbf{A}^{\mathrm{T}}$ T last the Infantile Cerebral Palsied Children have caught the eye of the health anthorities in South Africa. They have been brought out of - as W. M. Phelps says - the farthest and darkest corner of our national conscience, where they have been stowed away, neglečted and forgotten. Yet they are still far from attaining all the publicity and - in connection with it - all the funds which their more popular brothers and sisters, the polio children, get. And this although the incidence of Cerebral Palsy is about as high as polio.
\end{abstract}

Until the present day three government schools the schools for plyysically handicapped children in Kimberley - embarked, among other projects, upon the treatment of and research on Infantile Cerebral Palsy. Besides these three schools there exist two private schools for cerebral palsied children, one in Johannesburg and one in Pretoria. Cerebral Palsy cases are also accepted and schooling is provided for them by the Meerhof Children's Hospital and by the open-air school in Durban. Further it is this home, the Helen Bishop Home, and the "Hope Convalescent Home for Children" at Johannesburg which accept, treat and at the same time school these children.

If we speak of the treatment of Cerebral Palsy, then we refer only to relabilitation - if possible, and as far as possible - but not to cure. For a cure does not exist. And in the treatment the main thing is the patient and perseverant work of the physiotlierapist for years and years. For although many specialists work in the field of Cerebral Palsy it is the unanimous opinion of the leading cerepalsists of the world that concerning the reliabilitation of cerebral palsied children one profession stands right in the centre, and this is pliysiotherapy - physiotherapy inasfar as it undertakes neuromuscular education, or re-education by remedial exercises. All the other special fields like orthopædic surgery, neurosurgery, bracing, drugs, etc., are only adjuvants.

So: Cerebral Palsy is the ficld of the Physiotherapist.

One of the outstanding figures in physiotherapy for the cerebral palsied is Miss Paula Egel from the Children's Hospital, Buffalo, New York. She is a pupil of Dr. W. M. Phelps who is one of the greatest pioneers in the treatment of Cerebral Palsy. Miss Egel wrote an excellent book, titled, "Technique and Treatment for the Cerebral Palsy Child. * It is most clearly and concisely written and should be studied by every physiotherapist. Under the guidance of Miss Egel and Mr. Moir P. Tanner of the said hospital, a film on Cerebral Palsy treatment has also been composed. This film was first kindly lent to us

*St. Louis, 1948. by the Cerebral Palsy Association of Western New York, and later when we asked for prolongation of time wc received the best and shortest reply we ever got to a recuest: Keep it!

(The film, "Pionecring for America's Children," lemt by the Principal of the School for Physically Handi. capped Boys, Mr. V. Vaughan, was shozen by Dr. Obholser).

The impression given by this film is that physiotherapeutic treatment of cerebral palsied children is very difficult, as all cases differ widely. So one certainly nceds a sound knowledge of remedial exercises. 33ut what one needs above all is constant study of each single case in order to adapt one's personal knowledge to the given circumstances. One must experiment and carefully observe. Moreover, one needs patience, perseverance and a good deal of horse-sense. One has to keep in touch with modern development in Cerebral Palsy, and study new publications, for Cerebral Palsy is rapidly gaining field overseas and considerable research is being carried ont.

Let me now discuss one of our cases, just an average spastic one, but rather typical for how problem after problem arises witl each single patient.

X. 7 years 11 months. He cane to onr school $1 \frac{1}{3}$ years ago. In terms of the 1937 Act he was "a child in need of care"; his family circumstances were most unfortunate. He arrived at onr school barefoot, dirty, neglected and very shy. $\mathrm{He}$ walked with some difficulty, having a spastic gait and bearing his weight on the lateral dorsum of the riglit foot,' where a thick callus could be seen. The right arm was kept bent at the elbow and wrist and carried in front of the body. The right hand was half clenched to a fist. He mainly used the left hand, and could not dress himself. He stuttered badly, and often showed inspirational intonation. Apart from this, X showed no abnormality in the initial medical examination carried out by the senior medical officer of out school, Dr. H. G. Pretorius. The diagnosis made was Spastic Cerebral Hemiplegia. After that he was screened by our dental doctor and our psychologist who found his I.Q. to be 98 (individual scale); thus the boy was of normal intelligence, although his behaviour was difficult and he was very disobedient. $\mathrm{He}$ showed emotional instability.

$\mathrm{He}$ appeared to be quite a good case, being still rather young - as young as our school can accept children at the present time - and thus still mouldable. However, the treatment of Cerebral Palsied children should begin much earlier - as soon as their 
ation becomes apparent - and this is often the colldition bore children reach one year of age, which caic principle:

Slurt trealmont as early as possible.

So the little cliap was enrolled for a trial period months, and when he showed signs of improvement however slight they were, he was accepted for tiven, One should think twice before rejecting a child roved. One silt of the first medical examination. $1 t$ is on the resive him a chance by allowing a trial period of 3 months.

We know very little about the history of this W'e know that he was a breech birtl and that patient. Ong and difficult. Yet whether this accounts bor lis Cerebral Palsy we cannot say. It is somewat strange that his condition was not noticed before "hat stranther wrote to us: "he could walk well." '1iis remark resembles closely the statement of a re"lins results of the Bikini island atom pormbing. He said that although the goats survived they "would remain sterile for some generations." More observant mothers notice such a condition much carlicr. They usually soon see the difference in kicking between the right and the left leg, and the difference in gripping between the right and the left land. In our patient we must assume that it had existed since birth as in the first year we hear of no sickness - whooping cough was contracted later.

le now got good clothes and boots and was prond of them, and he went to the gymnasinm and to kinderraiten school. $\mathrm{He}$ received treatment by the occupational therapist as well as the speech therapist, and he also enjoyed spending some of his spare time in unr leisure department. $X$ had had no treatment whatsocver before he came to our school.

An accurate muscle test was carried out (using the muscle test cliart for spastics of the Phelps school). Hereby it was determined which muscles were spastic, normal, weak cerebral, or even zero cerebral. Fortumately there were no permanent contractures yet as witl older children, where an operation is then reguired. The muscle test took some weeks as this little man was not very co-operative. He soon tired and conld not concentrate for more than about 15 minutes at a time. And this brings me to another principle:

\section{It is essontial to secure the co-operation of the} paticnt.

Wc also tried to carry ont a faradic muscle test, but this frightened the little boy and had to be abandoned for good. We were not dismayed for we are not convinced of the value of either faradic muscle testing or faradic treatment for spastics and $I$ am pleased to say that our chairinan, Mr. F. H. Henry, confirms this opinion.

At the same time $\mathrm{X}$ became acquainted with remedial excrcises. These consisted - at least in the beginning - mainly of playing, alone or with others. Thereby le was carefully observed to determine future treatnent. Being allowed to play, he came to like the place, and this is very important for everybody, still more for children and above all for spastic children. The little boy then had his daily treatment period of 40 minutes in the gymnasium, partly individual and partly with a few other children of the same age. $X$ showed among other shortcomings, zero cerebral dorsinexors at the right foot which promptly responded to the "Confused Motion" treatment found by Phelps (i.e, resistance to hip-bending dorsiflexes ankle). X harl to walk from his living quarters to the school- room about a quarter of a mile away - or rather, he was usually transported by car. This was very unsatisfactory. So we succeeded in making hin like tricycling: A broad safe tricycle, which could not tumble over easily was given to him and after a few days he mastered it all right. Thus he was selfmobile, and at the same time had some excellent exercise for his spastic foot. Tricycles have been recommended for the treatment of spastic children over and over again - so e.g., by Mrs. Fischel and Mrs. Gratke * What makes tricycling so valuable is not only that reciprocal movement of feet, etc., helps in the newromuscular education of certain spastic children, but that tricycling is not boring; moreover it is great fun and thus used extensively. It is a complex movement and has a definite practical purpose. I must aclmit that of all the special muscle excrcises we could ofker this boy on the plinth or even in the gymnasinm, tricvcling was by far the best. In spasticity psychic tensions grossly inhibit freedom of movement. Thus it is of paramount importance that exercises are made enjoyable. And here we have another principle:

li.tercises should be enjoyable.

This is generally recognised although difficult to bring into practice.

The additional principle that

lixercises should be made up of complex movements zoith a practical purpose

is still the centre of some controversy.

In connection with this, tricycling experiments have been carried out in order to determine how the position of the spastic foot is influenced by cycling straight forward, circling to the right and to the left. 'The results liave been used for training.

Later $\mathrm{X}$ also got a scooter which he likes to ride in the big gymmasium. His spastic foot stands on the scooter and is prevented from the usual inverted position by a box keeping his foot straight. $\mathrm{He}$ became quite a scooter-expert and developed very good balance.

I have already mentioned that this little boy was treated by our speech therapist. In connection with his specel a special round table conference was called. It was attended by the principal of our school, the doctor, the two vice-principals, the psychologist, his remedial instructor, his hostel fathers and mothers, the occupational therapist, the speech therapist, the head of the leisure department, his teachers and a nurse to whom he is especially attached. The main question was whether immobilization of the boy's liealthy (left) hand should not be tried for a while. Why this? Because an occasionally found mirrorwriting with the left hand liad awakened our suspicion that he was innately right-handed and that his handedness had been violently, changed by Cerebral Palsy. So there was the possibility that this change of handedness might have caused the speech disturbance. Consequently immobilization of the left hand and the resultant increased practice by the affected hand might cause improvement of speech, which could be measured by making recordings. The idea behind this immobilization of the left hand was thus not an attempt to change his handedness primarily - a very doubtful thing - but just to find out what effect such a transitory change of handedness would liave on his speech. This problem, involved as it was by itself, became still more complicated by psychological

\footnotetext{
* Fischel, U.K. "The Spastic Child," St. Louis, 1937. McIntosh Gratke, Julictte, "Help Them Help Themselves," Dallas, 1947.
} 